\title{
ANALISIS PELAKSANAAN PENANGGULANGAN KEMISKINAN KABUPATEN KEDIRI TAHUN 2017
}

\author{
Dwi Susilowati \\ dwi_s@unisma.ac.id \\ Dosen Program Studi Agribisnis \\ Fakultas Pertanian \\ Universitas Islam Malang
}

\begin{abstract}
ABSTRAK
Penelitian ini berjudul Analisis Pelaksanaan Penanggulangan Kemiskinan Kabupaten Kediri Tahun 2017. Tujuan penelitian Menyusun Laporan Pelaksanaan Penanggulangan Kemiskinan (LP2KD) Tahun 2017; Mendeskripsikan capaian beserta kendala dan permasalahan pelaksanaan penanggulangan kemiskinan di Kabupaten Kediri tahun 2017

Metode penelitian yang dipergunakan dalam kegiatan ini adalah Analisis Deskriptif kuantitatif dan kualitatif. Hasil Penelitian ini antara lain: persentase penduduk miskin di Kabupaten Kediri dalam lima tahun ter-akhir menunjukkan trend menurun meskipun tidak terlalu progresif dengan rata-rata penurunan sebesar 0,28 persen per-tahun; tahun 2017, persentase penduduk miskin Kabupaten Kediri mengalami penurunan sebesar 0,47\% ( \pm 191ribu jiwa) terhadap kondisi tahun 2016; tahun 2017, capaian angka-angka kemiskinan berdasarkan dimensi ekonomi masih menunjukkan posisi lebih tinggi terhadap capaian Provinsi Jawa Timur maupun capaian secara Nasional; perkembangan TPT dalam 5 tahun terakhir menunjukkan trend menurun, dengan posisi capaian tahun 2017 di bawah capaian Provinsi Jawa Timur dan Nasional;
\end{abstract}

Kata kunci : Kebijakan, Ketenagakerjaan, Angkatan Kerja.

\section{PENDAHULUAN}

\section{Latar Belakang}

Kemiskinan (poverty) merupakan permasalahan fundamental yang sejak ber-abadabad lalu hingga saat ini masih dihadapi oleh bangsa-bangsa di dunia, termasuk juga Indonesia. Oleh karena itu permasalahan kemiskinan harus segera ditangani melalui implementasi langkah-langkah penanggulangan dan pendekatan yang sistematis, terpadu dan menyeluruh. Penanggulangan kemiskinan diarahkan untuk mengurangi beban rakyat miskin dan memenuhi hak-hak dasar warga negara secara layak melalui pembangunan inklusif, berkeadilan, dan berkelanjutan untuk mewujudkan kehidupan yang bermartabat.

Penanggulangan kemiskinan sebagai agenda global sebagaimana tertuang dalam Tujuan Pembangunan Berkelanjutan (SDG's), maka kebijakan pem-bangunan di Indonesia baik pusat maupun daerah diprioritaskan untuk program-program dan kegiatan-kegiatan penanggulangan kemiskinan. Bentuk komitmen Pemerintah terhadap penanganan kemiskinan, program penanggulangan kemiskinan telah menjadi bagian dari rencana pembangunan Pemerintah Pusat maupun Pemerintah Daerah, baik Rencana Pembangunan Jangka Panjang (RPJP) maupun Rencana Pembangunan Jangka Menengah (RPJM).

Sebagaimana tertuang dalam Undang-Undang Dasar 1945 dan Undang-Undang Nomor 23 tahun 2014 tentang Pemerintahan Daerah, dinyatakan bahwa: "Kepala Daerah 
dan Wakil Kepala Daerah mempunyai kewajiban meningkatkan kesejahteraan rakyat”. Hal ini secara implisit berarti penanggulangan kemiskinan harus diupayakan demi tercapainya kesejahteraan rakyat. Hasil pembangunan hendaknya dapat dinikmati secara lebih merata dan adil bagi seluruh lapisan masyarakat sebagai wujud peningkatan kesejahteraan lahir dan batin. Upaya penanggulangan kemiskinan akan dinyatakan efektif bila menunjukkan indikasi menurunnya jumlah penduduk miskin, bertambahnya tingkat pen-dapatan individu, dan menguatnya daya beli masyarakat. Lahirnya Peraturan Presiden No. 15 Tahun 2010 tentang Percepatan Penanggulangan Kemiskinan merupakan wujud intervensi Pemerintah untuk meningkatkan efektivitas penanggulangan kemiskinan. Upaya percepatan penanggulangan kemiskinan tidak hanya menjadi tanggung jawab Pemerintah pusat tetapi menyeluruh hingga ke tingkat daerah. Untuk itu perlu dilakukan koordinasi guna menjaga konsistensi dan efektivitas penanggulangan kemiskinan, sehingga dibentuklah Tim Koordinasi Penanggulangan Kemiskinan (TKPK) di tingkat Provinsi dan Kabupaten/Kota. Mekanisme kerja tim ini diatur dalam Peraturan Menteri Dalam Negeri No. 42 Tahun 2010 sebagai salah satu mitra kerja Tim Nasional Percepatan Penanggulangan Kemiskinan (TNP2K) yang merupakan wadah koordinasi di tingkat Nasional.

Tugas TKPK Kabupaten sebagaimana tertuang dalam pasal 10 Peraturan Menteri Dalam Negeri No. 42 Tahun 2010 tentang Tim Koordinasi Penanggulangan Kemiskinan Provinsi dan Kabupaten/Kota adalah melakukan koordinasi serta mengendalikan pelaksanaan penanggulangan kemiskinan. TKPK Kabupaten memiliki kewajiban untuk menyampaikan Laporan Tahunan Pelaksanaan Penanggulangan Kemiskinan Daerah (LP2KD). Laporan tersebut dapat diguna-kan untuk menilai efektifitas program penanggulangan kemiskinan dalam pembangunan. Sehingga laporan ini bermanfaat sebagai bahan pertimbangan dalam penyusunan perencanaan pembangunan yang akan datang.

\section{Tujuan Penelitian}

Penyusunan dokumen Laporan Pelaksanaan penanggulangan Kemiskinan Daerah (LP2KD) Kabupaten Kediri tahun 2017 dimaksudkan untuk menyediakan dokumen LP2KD di Kabupaten Kediri yang sesuai dengan acuan dan ketentuan yang berlaku.

Adapun tujuan pelaksanaan kegiatan penyusunan LP2KD tahun 2017 di Kabupaten Kediri adalah:

1. Menyusun Laporan Pelaksanaan Penanggulangan Kemiskinan (LP2KD) Tahun 2017;

2. Mendeskripsikan capaian beserta kendala dan permasalahan pelaksanaan penanggulangan kemiskinan di Kabupaten Kediri tahun 2017.

\section{Kondisi Kemiskinan Multidimensi di Kabupaten Kediri \\ 1. Dimensi Ekonomi dan Ketenagakerjaan}

Untuk mengetahui kondisi kemiskinan dari dimensi ekonomi adalah dengan melihat capaian dan perkembangan jumlah dan persentase penduduk miskin, indeks kedalaman kemiskinan, serta indeks keparahan kemiskinan. Sedangkan dimensi ketenagakerjaan dengan melihat capaian dan perkembangan tingkat pengangguran terbuka dan setengah pengangguran.

\section{Persentase Penduduk Miskin}


Persentase penduduk miskin di Kabupaten Kediri pada tahun 2017 adalah sebesar 12,25 persen, mengalami penurunan sebesar 0,47 persen jika dibandingkan tahun 2016. Bila dibandingkan dengan persen-tase penduduk miskin Provinsi Jawa Timur maupun Nasional, maka persentase penduduk miskin Kabupaten Kediri masih lebih tinggi. Di antara Kabupaten/Kota di Provinsi Jawa Timur, persentase penduduk miskin Kabupaten Kediri (pada tahun 2017) menempati urutan ke 23.

Perkembangan persentase penduduk miskin di Kabupaten Kediri selama periode 20132017, menunjukkan perkembangan angka yang bersifat fluk-tuatif, dengan perkembangan secara keseluruhan menunjukkan trend menurun, dengan rata-rata penurunan angka sebesar 0,28 persen per-tahun.

Perkembangan tingkat kemiskin-an yang menunjukkan trend me-nurun, mengindikasikan bahwa kebijakan dan program yang di-upayakan Pemerintah Kabupaten Kediri dalam rangka menurunkan persentase penduduk miskin dapat berjalan dengan efektif dan berdampak positif dalam mengurangi angka kemiskinan.

Selama periode 2013-2017, trend perkembangan persentase penduduk miskin Kabupaten Kediri menunjukkan trend yang sama (relevan) dengan perkembangan di tingkat Provinsi Jawa Timur maupun secara Nasional. Meskipun memiliki trend yang relevan, akan tetapi percepatan penurunan angka kemiskinan di Kabupaten Kediri hanya sekitar 68 persen dari rata-rata percepatan penurunan angka kemiskinan di Provinsi Jawa Timur dan sekitar 82 persen dari rata-rata per-cepatan penurunan di tingkat Nasional.

Perkembangan tingkat kemis-kinan yang relevan antara per-kembangan Kabupaten Kediri dengan Provinsi Jawa Timur maupun Nasional menjadi indi-kasi bahwa upaya-upaya yang telah dilakukan oleh Pemerin-tah Kabupaten Kediri dalam menurunkan tingkat kemiskinan melalui program dan kegiatan pembangunan telah sejalan dengan upaya di tingkat Provinsi maupun secara Nasional.

\section{Jumlah Penduduk Miskin}

Dengan persentase penduduk miskin sebesar 12,25 persen, jumlah penduduk miskin di Kabupaten Kediri pada tahun 2017 adalah sebanyak 191.082 jiwa. Pada tahun yang sama, jumlah penduduk miskin di provinsi Jawa Timur adalah sebesar 4.617.010 ribu jiwa dan total penduduk miskin secara Nasional adalah sebesar 27.771,2 ribu jiwa. Dengan demikian Kabupaten Kediri pada tahun 2017 memberikan kontribusi sebesar 4,34 persen terhadap jumlah penduduk miskin di Provinsi Jawa Timur dan sebesar 0,72 persen pada jumlah penduduk miskin secara Nasional.

Perkembangan Jumlah penduduk miskin di Kabupaten Kediri selama tahun 20132017, menunjukkan per-kembangan angka yang bersifat fluktuatif dengan trend perkembangan secara keseluruhan me-nunjukkan trend menurun, dan jumlah penduduk miskin pada tahun 2017 lebih rendah dari tahun 2013.

\section{Indeks Kedalaman Kemiskinan (P1)}

Indeks kedalaman kemiskinan di Kabupaten Kediri pada tahun 2017 adalah sebesar 1,71 persen meningkat sebesar 0,09 persen jika dibandingkan dengan kondisi tahun 2016. Pada tahun yang sama indeks kedalaman kemiskinan di Provinsi Jawa Timur sebesar 1,87 sedangkan indeks secara Nasional sebesar 1,83, maka dapat dikatakan bahwa kesenjangan pengeluaran penduduk miskin terhadap garis kemiskinan di Kabupaten Kediri masih lebih 
rendah (lebih baik) karena berada di bawah tingkat kesenjangan di tingkat Provinsi maupun Nasional.

Di antara Kabupaten/Kota di Provinsi Jawa Timur,

Perkembangan indeks kedalaman kemiskinan di Kabupaten Kediri selama periode 2013-2017, me-nunjukkan perkembangan angka yang bersifat fluktuatif dengan trend menurun. Dan kondisi ca-paian pada tahun 2017 lebih ren-dah dari tahun 2013.

Perkembangan indeks kedalaman kemiskinan yang menunjukkan trend me-nurun, mengindikasikan bahwa tingkat kesejahteraan penduduk miskin semakin membaik. Dengan demikian kebijakan maupun program yang telah diupayakan Pemerintah Kabupaten Kediri dalam rangka memperkecil ke-senjangan pengeluaran penduduk miskin terhadap garis kemiskinan dapat berjalan efektif dan berdampak positif.

Selama periode 2013-2017, trend perkembangan indeks kedalaman ke-miskinan di Kabupaten Kediri menunjukkan trend yang sama (relevan) dengan perkembangan di Provinsi Jawa Timur.

Relevansi perkembangan indeks kedalaman kemiskinan antara Kabupaten Kediri dengan di Provinsi Jawa Timur dan Nasional menjadi indikasi bahwa upaya-upaya yang telah dila-kukan oleh Pemerintah Kabu-paten Kediri dalam memper-kecil nilai indeks kedalaman kemiskinan melalui program dan kegiatan pembangunan telah sejalan dengan upaya-upaya di tingkat Provinsi Jawa Timur maupun secara Nasional.

\section{Indeks Keparahan Kemiskinan (P2)}

Indeks keparahan kemiskinan di Kabupaten Kediri pada tahun 2017 adalah sebesar 0,39 persen meningkat sebesar 0,02 persen jika dibandingkan dengan tahun 2016. Pada tahun yang sama indeks kedalaman kemiskinan di Provinsi Jawa Timur sebesar 0,45 sedangkan indeks secara Nasional sebesar 0,48, maka dapat dikatakan bahwa ketimpangan pengeluaran antar penduduk miskin di Kabupaten Kediri masih sedikit lebih rendah (lebih baik) terhadap tingkat kesenjangan di Provinsi Jawa Timur.

Perkembangan indeks keparahan kemiskinan di Kabupaten Kediri selama periode 2013-2017, menunjukkan perkembangan angka yang bersifat fluktuatif dengan trend perkembangan secara keseluruhan menunjukkan trend menurun.

Perkembangan indeks keparahan kemiskinan yang menunjukkan trend menurun, mengindikasikan bahwa tingkat kesejahteraan pen duduk miskin di Kabupaten Kediri semakin membaik. Dengan de-mikian kebijakan maupun pro-gram yang telah diupayakan oleh Pemerintah Kabupaten Kediri dalam rangka memperkecil ke-senjangan pengeluaran antar penduduk miskin dapat berjalan efektif dan berdampak positif dalam mempersempit kesenjangan antar penduduk miskin di Kabupaten Kediri.

Selama periode 2013-2017, trend perkembangan indeks keparahan kemis-kinan di Kabupaten Kediri menunjukkan trend yang sama (relevan) dengan perkembangan di Provinsi Jawa Timur.

Perkembangan indeks keparahan kemiskinan yang menunjukkan relevansi antara perkembangan di Kabupaten Kediri dengan di Provinsi Jawa Timur menjadi indikasi bahwa upaya-upaya yang telah dilakukan Pemerintah Kabupaten Kediri dalam memperkecil nilai indeks keparahan kemiskinan melalui program dan kegiatan pemba-ngunan telah sejalan dengan upaya-upaya di tingkat Provinsi Jawa Timur.

Tingkat kemiskinan Kabupaten Kediri pada tahun 2017 berada diangka 12,25\%. Jika menggunakan standar target yang termuat pada dokumen RPJMN (Rencana 
Pembangunan Jangka Panjang Nasional) 2015-2019, angka kemiskinan nasional ditargetkan turun menjadi sebesar 8\% (target ideal) sampai dengan $10 \%$ (target konservatif). Dengan tolok ukur tersebut dan mengacu pada capaian tingkat kemiskinan di tahun 2017, Kabupaten Kediri masih perlu untuk mengejar target ideal nasional.

\section{Dimensi Pendidikan}

Kondisi kemiskinan ditinjau dari dimensi pendidikan di Kabupaten Kediri dilakukan dengan melihat perkembangan capaian indikator-indikator dimensi pendidikan selama kurun waktu 2013-2017 (5 tahun terakhir) dan capaian indikator-indikator tersebut pada tahun terakhir terhadap capaian tahun yang sama di tingkat Provinsi Jawa Timur dan Nasional.

Perkembangan capaian indikator dimensi pendidikan: Dari 10 indikator pada dimensi pendidikan di Kabupaten Kediri selama periode tahun 2013-2017, indikator APK $\mathrm{SD} / \mathrm{Mi}$ menunjukkan trend perkembangan capaian yang menurun (memburuk), dan capaian tahun 2017 lebih rendah dari tahun sebelumnya. Indikator APtS semua usia juga menunjukkan trend perkembangan yang memburuk (meningkat), dengan capaian APtS usia 7-12 tahun dan usia 16-18 tahun untuk tahun 2017 lebih tinggi dari tahun sebe-lumnya, sedangkan capaian APtS usia 13-15 tahun untuk tahun 2017 masih lebih baik (turun) terhadap tahun sebelumnya. Sementara itu 5 indikator lainnya menunjukkan perkembangan dengan trend yang konsisten membaik.

\section{Dimensi Kesehatan}

Kondisi kemiskinan ditinjau dari dimensi kesehatan di Kabupaten Kediri dilakukan dengan melihat perkembangan capaian indikator-indikator bidang kesehatan selama kurun waktu 2012-2015 (5 tahun terakhir) dan capaian indikator-indikator tersebut pada tahun terakhir terhadap capaian tahun yang sama di tingkat Provinsi Jawa Timur dan Nasional.

Perkembangan capaian indikator dimensi kesehatan: Seluruh indikator pada dimensi kesehatan di Kabupaten Kediri selama tahun 2013-2017 menunjukkan perkembangan capaian yang fluktuatif. Indikator AKB per 1000 kelahiran hidup AKI per 100 ribu kelahiran hidup, dan indikator prevalensi balita kekurangan gizi menunjukkan trend perkemba-ngan capaian yang menurun. Untuk indikator AKB per 1000 kelahiran hidup juga masih menunjukkan trend perkembangan capaian yang me-nurun, meskipun capaian tahun 2017 lebih tinggi dibandingkan tahun sebelumnya. Sementara itu untuk indikator proporsi persalinan di tolong tenaga kesehatan terlatih menunjukkan trend perkembangan menurun dalam 2 tahun terakhir.

\section{Dimensi Prasarana/Infrastruktur Dasar}

Kondisi kemiskinan ditinjau dari dimensi prasarana/infrastruktur dasar di Kabupaten Kediri dilakukan dengan melihat perkembangan capaian indikator-indikator bidang prasarana dasar selama kurun waktu 2013-2017 (5 tahun terakhir) dan capaian indikatorindikator tersebut pada tahun terakhir terhadap capaian tahun yang sama di tingkat Provinsi Jawa Timur dan Nasional.

Perkembangan capaian indikator bidang prasarana dasar: Dari 5 indikator pada dimensi prasarana/infrastruktur dasar di Kabupaten Kediri selama periode tahun 20132017, hanya indikator proporsi rumah tangga dengan akses air minum layak yang tidak menunjukkan masalah, baik berdasarkan capaian pada tahun 2017 yang lebih baik terhadap tahun sebelumnya maupun berdasarkan deret waktu meskipun berfluktuatif tetapi masih 
menunjukkan trend perkembangan yang cenderung meningkat (membaik). Indikator proporsi rumah tangga dengan akses sanitasi dasar layak berkelanjutan; rumah tangga dengan akses penerangan listrik (PLN dan Non-PLN); dan indikator proporsi rumah tangga dengan status kepemilikan milik sendiri, meski menunjukkan trend perkembangan yang cenderung meningkat (membaik) akan tetapi capaian pada tahun 2017 lebih rendah terhadap capaian tahun sebelumnya. Sementara untuk indikator proporsi rumah tidak layak huni, hanya tersedia data untuk 2 (dua) tahun terakhir, dengan capaian tahun 2017 lebih rendah (lebih baik) terhadap tahun sebelumnya.

\section{Dimensi Ketahanan Pangan}

Kondisi kemiskinan ditinjau dari dimensi ketahanan pangan di Kabupaten Kediri dilakukan dengan melihat perkembangan capaian indikator-indikator bidang ketahanan pangan selama kurun waktu 2013-2017 (5 tahun terakhir) dan capaian indikator-indikator tersebut pada tahun terakhir terhadap capaian tahun yang sama di tingkat Provinsi Jawa Timur dan Nasional.

Perkembangan capaian indikator bidang ketahanan pangan: Dari indikatorindikator pada dimensi ketahanan pangan di Kabupaten Kediri selama periode tahun 20132017, hampir semua indikator menun-jukkan perkembangan capaian yang fluktuatif dari tahun ketahun dengan kecenderungan rata-rata harga pada tahun terakhir (tahun 2017) lebih tinggi dari tahun sebelumnya, kecuali pada gula pasir, daging ayam ras, dan telur ayam ras, serta beberapa komoditi sayur mayur.

\section{HASIL DAN PEMBAHASAN}

\section{Regulasi Daerah tentang Penanggulangan Kemiskinan}

Kebijakan Pemerintah Kabupaten Kediri dalam upaya-upaya penanggulangan kemiskinan, secara legalitas berupa Peraturan Daerah Kabupaten Kediri dan Peraturan Bupati Kediri sebagaimana terperinci pada tabel berikut.

Tabel 1,

Peraturan Daerah/Peraturan Bupati yang Berkaitan dengan Penanganan Kemiskinan di Kabupaten Kediri

\begin{tabular}{|c|l|l|l|}
\hline No. & \multicolumn{1}{|c|}{$\begin{array}{c}\text { Peraturan Daerah/ } \\
\text { Peraturan Bupati }\end{array}$} & \multicolumn{1}{|c|}{ Peraturan Tentang } & \multicolumn{1}{|c|}{$\begin{array}{c}\text { Keterkaitan dengan } \\
\text { Penanggulangan Kemiskinan }\end{array}$} \\
\hline$(1)$ & \multicolumn{1}{|c|}{$(2)$} & \multicolumn{1}{c|}{$(3)$} & \multicolumn{1}{c|}{ (4) } \\
\hline \hline 1. & $\begin{array}{l}\text { SK Bupati No. 188.45/ } \\
140 / 418.08 / 2017 \text { Tahun } \\
2017\end{array}$ & $\begin{array}{l}\text { Tim Koordinasi Penanggu- } \\
\text { langan Kemiskinan Kabu- } \\
\text { paten Kediri Tahun 2017 }\end{array}$ & $\begin{array}{l}\text { Koordinasi dan pengendalian } \\
\text { penanggulangan kemsimkin-an } \\
\text { di Kabupaten Kediri }\end{array}$ \\
\hline
\end{tabular}

Sumber: Bappeda Kab. Kediri - data diolah

\section{Program dan Kegiatan Penanggulangan Kemiskinan}

Dalam upaya penanggulangan kemiskinan, Pemerintah di berbagai tingkatan (pusat, provinsi dan kabupaten/kota) telah menetapkan kebijakan dan program penanggulangan kemiskinan yang terdiri dari 4 (empat) kelompok program atau klaster, yaitu:

- Kelompok program bantuan sosial terpadu berbasis keluarga, ber-tujuan untuk melakukan pemenuhan hak dasar, pengurangan beban hidup, dan perbaikan kualitas hidup masyarakat miskin;

- Kelompok program penanggulangan kemiskinan berbasis pemberdayaan masyarakat, bertujuan untuk mengembangkan potensi dan memperkuat kapasitas kelompok 
masyarakat miskin untuk terlibat dalam pembangunan yang didasarkan pada prinsipprinsip pemberdayaan masyarakat;

口 Kelompok program penanggulangan kemiskinan berbasis pemberdayaan usaha ekonomi mikro dan kecil, bertujuan untuk memberikan akses dan penguatan ekonomi bagi pelaku usaha berskala mikro dan kecil; dan

口 Program-program lainnya yang baik secara langsung ataupun tidak langsung dapat meningkatkan kegiatan ekonomi dan kesejahteraan masyarakat miskin.

Program penanggulangan kemiskinan yang merupakan program Nasional baik yang pernah dan tengah berlangsung di Kabupaten Kediri menurut klaster program adalah sebagai berikut:

1) Program Nasional dan Program Daerah yang Mendukung:

Program-program penanggulangan kemiskinan tahun 2017 yang merupakan program Pemerintah (program Nasional dengan sumber pembiayaan program berasal dari APBN) di Kabupaten Kediri, antara lain berikut ini:

$\square$ Program Indonesia Pintar (PIP);

$\square$ Program Jaminan Kesehatan Nasional (Program JKN);

$\square$ Program Keluarga Harapan (PKH);

$\square$ Program Subsidi Beras Sejahtera (Rastra).

2) Program Daerah/Sektoral (sumber pendanaan APBD Provinsi Jawa Timur dan Kabupaten Kediri):

Program-program penanggulangan kemiskinan tahun 2017 yang meru-pakan program Pemerintah Provinsi Jawa Timur adalah:

$\square$ Program Jalin Matra / Penarnggulangan Feminisasi Kemiskinan (PFK);

$\square$ Penanggulangan Kerentanan Kemiskinan (PK2); dan

$\square$ Bantuan Rumah Tangga Sangat Miskin (BFITSM)

Seluruhnya dengan alokasi anggaran sebesar Rp. 4,759,125.000,- dengan sumber pembiayaan APBD Provinsi jawa Timur.

Adapun Program/Kegiatan Penanggulangan Kemiskinainan yang dilak-sanakan oleh SKPD-SKPD di Kabupaten Kediri, adalah berikut ini:

Tabel 2,

Program/Kegiatan Penanggulangan Kemiskinan Kabupaten Kediri dengan Sumber Pembiayaan APBD Kabupaten Kediri Tahun 2017

\begin{tabular}{|l|l|l|l|}
\hline $\begin{array}{l}\text { Organisasi } \\
\text { Perangkat Daerah }\end{array}$ & $\begin{array}{l}\text { Program/Kegiatan Penanggulangan } \\
\text { Kemiskinan }\end{array}$ & $\begin{array}{l}\text { Alokasi Anggaran } \\
\text { (Rp) }\end{array}$ & $\begin{array}{l}\text { Usulan } \\
\text { PAPBD-2017 } \\
\text { (Rp) }\end{array}$ \\
\hline$(1)$ & $(2)$ & $(3)$ & $(4)$ \\
\hline $\begin{array}{l}\text { Dinas Pengendalian } \\
\text { Penduduk, Keluarga } \\
\text { Berencana dan } \\
\text { Perlindungan Anak }\end{array}$ & $\begin{array}{l}\text { 1. Peningkatan peran serta perempuan di } \\
\text { pedesaan } \\
\text { 2. Peningkatan peran serta dan kesetaraan } \\
\text { gender dalam pembangunan }\end{array}$ & 38.000 .000 & 200.000 .000 \\
3. Keluarga Berencana & $\begin{array}{l}\text { 1. Pengembangan budidaya ikan di kolam } \\
\text { rakyat }\end{array}$ & 57.940 .000 & 38.500 .000 \\
\hline 2. Pengembangan pembenihan ikan & & \\
\hline
\end{tabular}




\begin{tabular}{|c|c|c|c|}
\hline $\begin{array}{l}\text { Organisasi } \\
\text { Perangkat Daerah }\end{array}$ & $\begin{array}{l}\text { Program/Kegiatan Penanggulangan } \\
\text { Kemiskinan }\end{array}$ & $\begin{array}{l}\text { Alokasi Anggaran } \\
\text { (Rp) }\end{array}$ & $\begin{array}{l}\text { Usulan } \\
\text { PAPBD-2017 } \\
\text { (Rp) }\end{array}$ \\
\hline$(1)$ & (2) & (3) & $(4)$ \\
\hline $\begin{array}{l}\text { Dinas Pekerjaan Umum } \\
\text { Penataan Ruang }\end{array}$ & $\begin{array}{l}\text { 1. Pembangunan saluran draina se/gorong- } \\
\text { gorong } \\
\text { 2. Rehabilitasi infrastrukrtur irigasi }\end{array}$ & $\begin{array}{l}500.000 .000 \\
2.254 .000 .000\end{array}$ & \\
\hline Dinas Pendidikan & $\begin{array}{l}\text { 1. Bantuan Khusus Siswa Miskin (BSM) } \\
\text { 2. Gerakan Nasional Orangtua Asuh } \\
\text { (GNOTA) }\end{array}$ & $\begin{array}{l}1.919 .580 .000 \\
10.000 .000 .000\end{array}$ & \\
\hline Dinas Kesehatan & $\begin{array}{l}\text { 1. KIS / PBI-JKN } \\
\text { 2. Jamkesda } \\
\text { 3. Pengadaann susu melalui PKK } \\
\text { 4. STBM }\end{array}$ & $\begin{array}{l}168.457 .428 .000 \\
4.000 .000 .000 \\
355.000 .000 \\
1.345 .000 .000\end{array}$ & \\
\hline Dinas Perdagang an & $\begin{array}{l}\text { 1. Peningkatan kemampuan industri olahan } \\
\text { makanan dan minuman } \\
\text { 2. Peningkatan dan pengembang an } \\
\text { teknologi industri kera jinan }\end{array}$ & $\begin{array}{l}480.500 .000 \\
61.975 .000\end{array}$ & \\
\hline \multirow[t]{2}{*}{$\begin{array}{l}\text { Dinas Pariwisata dan } \\
\text { Kebudayaan }\end{array}$} & $\begin{array}{l}\text { 1. Pengembangan destimasi pa riwisata } \\
\text { unggulan, kegiatan pengembangan daerah } \\
\text { tujuan wisata }\end{array}$ & 130.725 .000 & \\
\hline & $\begin{array}{l}\text { 2. Pengelolaan kekayaan budaya daerah, } \\
\text { kegiatan pengembang an daerah tujuan } \\
\text { wisata } \\
\text { 3. Pengelolaan keragaman buda ya kegiatan } \\
\text { pengembangan kesenian dan budaya } \\
\text { daerah } \\
\text { 4. Pengembangan kerjasama pe ngelolaan } \\
\text { kekayaan budaya, ke giatan fasilitasi } \\
\text { pembentukan kemitraan usaha profesi } \\
\text { antar daerah } \\
\text { 5. Pegembangan destinasi pariwi sata } \\
\text { unggulan, kegiatan sosia lisasi dan } \\
\text { penerapan serta pe ngawasan } \\
\text { standardisasi }\end{array}$ & $\begin{array}{l}187.250 .000 \\
988.450 .000 \\
351.857 .750 \\
108.800 .000\end{array}$ & \\
\hline $\begin{array}{l}\text { Dinas Koperasi dan } \\
\text { Usaha Mikro }\end{array}$ & $\begin{array}{l}\text { 1. Pelatihan perkoperasian } \\
\text { 2. Monitoring, evaluasi dan pelaporan } \\
\text { 3. Bimtek perkoperasian } \\
\text { 4. Pelatihan ketrampilan } \\
\text { 5. Pemberdayaan dan pedam pingan rumah } \\
\text { produk unggulan } \\
\text { 6. Inventarisasi dan sinkronisa si UMKM }\end{array}$ & $\begin{array}{l}44.500 .000 \\
490.000 .000\end{array}$ & $\begin{array}{l}270.000 .000 \\
78.000 .000 \\
225.000 .000 \\
875.000 .000 \\
272.200 .000\end{array}$ \\
\hline
\end{tabular}




\begin{tabular}{|c|c|c|c|}
\hline $\begin{array}{l}\text { Organisasi } \\
\text { Perangkat Daerah }\end{array}$ & $\begin{array}{l}\text { Program/Kegiatan Penanggulangan } \\
\text { Kemiskinan }\end{array}$ & $\begin{array}{l}\text { Alokasi Anggaran } \\
\text { (Rp) }\end{array}$ & $\begin{array}{l}\text { Usulan } \\
\text { PAPBD-2017 } \\
\text { (Rp) }\end{array}$ \\
\hline \multirow[t]{2}{*}{ (1) } & (2) & (3) & (4) \\
\hline & $\begin{array}{l}\text { 7. Promosi produk usaha mikro } \\
\text { 8. Diklat pemasaran melalui e-comerce } \\
\text { bagi UMKM pra-sejahtera (KUBE) } \\
\text { 9. Pembuatan baliho usaha mikro } \\
\text { 10. Pembuatan pamflet/brosur usaha mikro } \\
\text { 11. Publikasi usaha mikro mela lui media }\end{array}$ & 201.725 .000 & $\begin{array}{l}60.900 .000 \\
75.600 .000 \\
84.000 .000 \\
224.000 .000\end{array}$ \\
\hline \multirow[t]{2}{*}{ Dinas Sosial } & $\begin{array}{l}\text { 1. Program perlindungan dan ja minan } \\
\text { sosial/kegiatan pendam pingan } \mathrm{PKH}\end{array}$ & 355.152 .500 & \\
\hline & $\begin{array}{l}\text { 2. Pegembangan destinasi pariwi sata } \\
\text { unggulan, kegiatan sosia lisasi dan } \\
\text { penerapan serta pe ngawasan } \\
\text { standardisasi } \\
\text { 3. Pendampingan kube fakir miskin } \\
\text { 4. Peltihan WRSE } \\
\text { 5. Pelatihan dan bantuan perlin dungan } \\
\text { sosial pekerja migran }\end{array}$ & $\begin{array}{l}108.800 .000 \\
72.000 .000 \\
50.000 .000 \\
25.000 .000\end{array}$ & \\
\hline $\begin{array}{lr}\text { Dinas Pemberda yaan } \\
\text { Masyarakat } & \text { dan } \\
\text { Pemerintahan Desa }\end{array}$ & $\begin{array}{l}\text { 1. Program Pemugaran Perumah an } \\
\text { Lingkungan Desa Terpadu (P2LDT) }\end{array}$ & 13.185 .000000 & \\
\hline Dinas Tenaga Kerja & $\begin{array}{l}\text { 1. Peltihan kewirausahaan } \\
\text { 2. Padat karya }\end{array}$ & $\begin{array}{l}40.000 .000 \\
3.075 .000 .000\end{array}$ & \\
\hline \begin{tabular}{|lr} 
Dinas & Ketahanan \\
Pangan dan Peter nakan
\end{tabular} & $\begin{array}{l}\text { 1. Peningkatan ketahanan pangan } \\
\text { optimalisasi pekarang an mela lui konsep } \\
\text { kawasan rumah pangan lestari }\end{array}$ & 140.000 .000 & \\
\hline \begin{tabular}{|l|} 
Dinas Pertanian dan \\
Perkebunan
\end{tabular} & $\begin{array}{l}\text { 1. Pemanfaatan pekarangan } \\
\text { 2. Hibah bibit hortikultura } \\
\text { 3. Pengembangan data dan infor masi } \\
\text { pertanian } \\
\text { 4. Penyediaan dan pengembang an sarana } \\
\text { dan prasarana per tanian } \\
\text { 5. Peremajaan tanaman kelapa } \\
\text { 6. Rehabilitasi dan pengembang an } \\
\text { tanaman cengkeh } \\
\text { 7. Rehabilitasi dan pengembang an } \\
\text { tanaman kopi } \\
\text { 8. Penanaman panen dan pasca panen } \\
\text { kakao } \\
\text { 9. Gelar teknologi dan pelatihan teknis }\end{array}$ & $\begin{array}{l}47.000 .000 \\
400.000 .000 \\
690.000 . .000 \\
3.216 .000 .000 \\
270.000 .000 \\
75.000 .00 \\
40.000 .000 \\
60.000 .000 \\
170.000 .000\end{array}$ & \\
\hline
\end{tabular}




\begin{tabular}{|l|l|l|l|}
\hline $\begin{array}{l}\text { Organisasi } \\
\text { Perangkat Daerah }\end{array}$ & $\begin{array}{l}\text { Program/Kegiatan Penanggulangan } \\
\text { Kemiskinan }\end{array}$ & $\begin{array}{l}\text { Alokasi Anggaran } \\
(\mathbf{R p})\end{array}$ & $\begin{array}{l}\text { Usulan } \\
\text { PAPBD-2017 } \\
(\mathbf{R p})\end{array}$ \\
\hline \hline 1$)$ & $(2)$ & $(3)$ & $(4)$ \\
\hline & $\begin{array}{l}\text { pertanian } \\
\text { 10. Pengembangan tanaman pangan }\end{array}$ & 250.000 .000 & \\
\hline
\end{tabular}

\begin{tabular}{|c|c|c|}
\hline & $\begin{array}{l}\text { 11. Peningkatan produksi, produk tifitas dan } \\
\text { mutu hasil tanaman pangan }\end{array}$ & 4.785.250.000 \\
\hline $\begin{array}{l}\text { Dinas Perumahan dan } \\
\text { Kawasan per mukiman }\end{array}$ & $\begin{array}{l}\text { 1. Pendukung Pamsimas } \\
\text { 2. Fasilitasi program BSPS bagi masyarakat } \\
\text { berpenghasilan rendah dan Peningkatan } \\
\text { Kualitas Perumahan (KPK) }\end{array}$ & $\begin{array}{l}161.790 .000 \\
300.000 .000\end{array}$ \\
\hline Bagian Perekono mian & $\begin{array}{l}\text { 1. Kegiatan pengawasan distribu si operasi } \\
\text { pasat khusus raskin } \\
\text { 2. Pasar murah dan pemberian paket } \\
\text { sembako gratis } \\
\text { 3. Bakti sosial terpadu bagi faskir miskin } \\
\text { 4. Pengawasan peredaran distri busi } \\
\text { BBM/LPG } \\
\text { 5. Antisipasi kelangkaan air bersih } \\
\text { 6. Sinkronisasi dan koordinasi ke } \\
\text { tersediaan pangan } \\
\text { 7. Pembinaan, pengembangan, dan } \\
\text { pemberdayaan masyara kat dan pelaku } \\
\text { usaha } \\
\text { 8. Pembinaan, pengembangan, dan } \\
\text { pemberdayaan masyara kat sentra } \\
\text { produk unggulan } \\
\text { 9. Pengembangan usaha ekono mi } \\
\text { produktif masyarakat } \\
\text { 10. Pembinaan dan pemberdaya an } \\
\text { pedagang kaki lima (PK5) dan asongan }\end{array}$ & $\begin{array}{l}290.815 .000 \\
900.609 .000 \\
202.464 .000 \\
90.500 .000 \\
250.000 .000 \\
150.000 .000 \\
397.000 .000 \\
\\
100.000 .000 \\
150.000 .000 \\
258.058 .000\end{array}$ \\
\hline Total & & 221.723 .839 .250 \\
\hline
\end{tabular}

Sumber: Bappeda Kabupaten Kediri

\section{Kelembagaan Tim Koordinasi Penanggulangan Kemiskinan}

Dalam melaksanakan program dan kegiatan penanggulangan kemiskinan, Pemerintah Kabupaten Kediri telah membentuk Tim Koordinasi Penanggu-langan Kemiskinan Kabupaten Kediri sebagaimana diatur dalam Peraturan Menteri Dalam Negeri nomor 42 tahun 2010, memiliki tugas dan fungsi sebagai berikut:

1) Melakukan Koordinasi Penanggulangan Kemiskinan di Kabupaten/Kota. Dalam menjalankan tugas tersebut, tim menjalankan fungsi: 
a. pengoordinasian penyusunan SPKD (Strategi Penanggulangan Kemiskinan Daerah) sebagai dasar penyusunan RPJMD (Rencana Pembangunan Jangka Menengah Daerah) bidang penanggulangan kemiskinan;

b. pengoordinasian Satuan Kerja Pemerintah Daerah (SKPD)/gabungan SKPD bidang penanggulangan kemiskinan dalam hal penyusunan rencana strategis SKPD;

c. pengoordinasian SKPD/gabungan SKPD bidang penanggulangan kemis-kinan dalam hal penyusunan rancangan RKPD (Rencana Kerja Pemerintah Daerah);

d. pengoordinasian SKPD/gabungan SKPD bidang penanggulangan kemis-kinan dalam hal penyusunan rencana kerja SKPD; dan

e. pengkoordinasian evaluasi pelaksanaan perumusan dokumen rencana pembangunan daerah bidang penanggulangan kemiskinan.

2) Mengendalikan Pelaksanaan Penanggulangan Kemiskinan di Kabupaten/ Kota. Dalam menjalankan tugas tersebut, tim menjalankan fungsi:

a. pengendalian pemantauan, supervisi dan tindak lanjut terhadap pencapai-an tujuan program dan kegiatan penanggulangan kemiskinan agar sesuai dengan kebijakan pembangunan;

b. pengendalian pemantauan pelaksanaan kelompok program penang-gulangan kemiskinan oleh SKPD yang meliputi realisasi pencapaian target, penyerapan dana dan kendala yang dihadapi;

c. penyusunan hasil pemantauan pelaksanaan program dan atau kegiatan program penanggulangan kemiskinan secara periodik;

d. pengendalian evaluasi pelaksanaan program dan atau kegiatan penanggulangan kemiskinan;

e. pengendalian penanganan pengaduan masyarakat bidang penanggu-langan kemiskinan;

f. penyiapan laporan pelaksanaan dan pencapaian program penanggu-langan kemiskinan kepada Bupati dan TKPK Provinsi.

Guna membantu kelancaran tugas Tim Koordinasi dibentuk:

1) Sekretariat Tim yang bertugas memberikan dukungan administrasi.

2) Tim Kelompok Kerja (Pokja) terdiri dari 3 (tiga) kelompok yaitu :

a. Pokja Pendataan dan Sistem Informasi, bertugas melaksanakan pengelo- laan data dan sistem informasi kemiskinan.

b. Pokja Pengembangan Kemitraan, bertugas mengembangkan kemitraan dalam penanggulangan kemiskinan.

c. Pokja Pengaduan Masyarakat, bertugas melaksanakan penanganan pengaduan masyarakat.

3) Tim Koordinator Program (Kelompok Program) terdiri:

a. Kelompok Program Bantuan Sosial Terpadu Berbasis Keluarga;

b. Kelompok Program Penanggulangan Kemiskinan Berbasis Pemberda-yaan Masyarakat;

c. Kelompok Program Penanggulangan Kemiskinan Berbasis Pemberda-yaan Usaha Ekonomi Mikro dan Kecil;

d. Kelompok Program Perluasan Kesempatan Kerja, Pemberdayaan Tenaga Kerja dan Perlindungan Sosial. 
Masing-masing kelompok program bertugas mengkoordinasikan kebijakan dan pengendalian pelaksanaan program penanggulangan kemiskinan sesuai pembidangannya.

Skema koordinasi dan pengendalian program penanggulangan kemiskinan oleh Tim Koordinasi Penanggulangan Kemiskinan sebagaimana dituangkan Peraturan Menteri Dalam Negeri Nomor 42 Tahun 2010 adalah dengan skema sebagaimana digambarkan pada diagram berikut.

\section{Gambar 1.}

Skema Koordinasi dan Pengendalian Program Penanggulangan Kemiskinan Berdasarkan Permendagri 42/2010

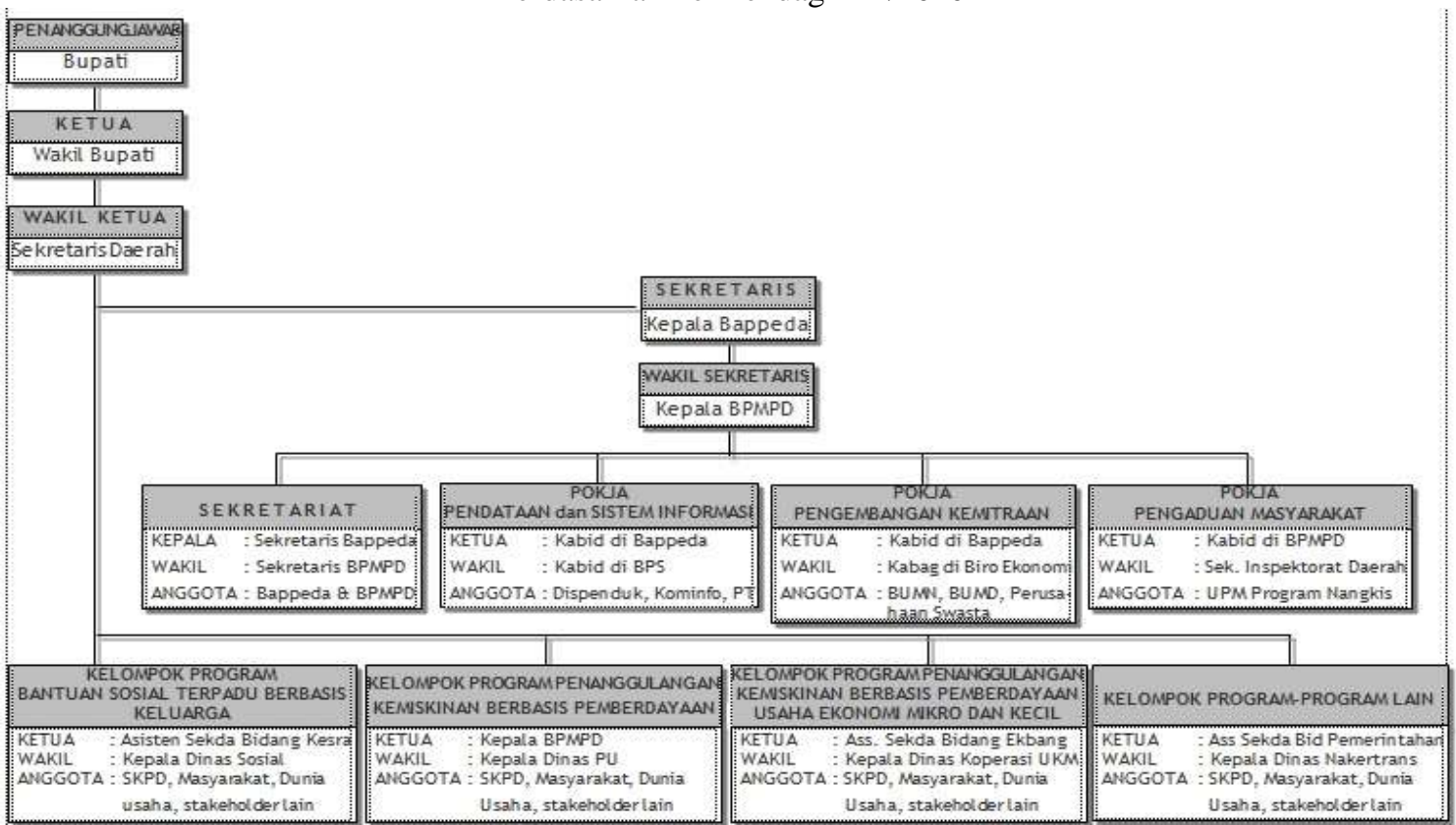

Sementara itu susunan Tim Koordinasi Penanggulangan Kemiskinan Kabupaten Kediri berdasarkan Surat Keputusan Bupati Kediri Nomor 188.45/140/418. 08/2017 adalah sebagai berikut:

A. SUSUNAN KEANGGOTAAN TKPK KABUPATEN KEDIRI:

Penanggung Jawab

Ketua

Wakil Ketua

Sekretaris

Wakil Sekretaris
Bupati

Wakil Bupati

Sekretaris Daerah

Kepala Bappeda

Kepala Dinas Pemberdayaan Masyarakat dan Pemerintahan Desa

Kelompok Program Bantuan Sosial Terpadu berbasis Keluarga:
a. Ketua
b. Wakil Ketua
c. Anggota

Asisten Pemerintahan dan Kesejahteraan Rakyat

Kepala Dinas Sosial

1) Kepala Dinas Pendidikan;

2) Kepala Dinas Kesehatan;

3) Direktur RSUD Pare;

4) Kepala BPS.

Kelompok Program berbasis Pemberdayaan Masyarakat:
a. Ketua
b. Wakil Ketua

Kepala Dinas Pemberdayaan Masyarakat dan Pemerintahan Desa Kepala Dinas Pekerjaan Umum dan 


\section{Penataan Ruang}

1) Kepala Dinas Ketahanan Pangan dan Peternakan;

2) Kepala Dinas Pariwisata dan Kebudayaan;

c. Anggota

3) Kepala Dinas Perikanan;

4) Kepala Dinas Pengendalian Penduduk, Keluarga Berencana, Pemberdayaan Perempuan dan Perlindungan Anak;

5) Kepala Dinas Perumahan dan Kawasan Pemukiman.

Kelompok Program berbasis Pemberdayaan Usaha Ekonomi Mikro dan Kecil:

a. Ketua

b. Wakil Ketua

c. Anggota
Asisten Perekonomian dan

Pembangunan

Mikro

1) Kepala Dinas Perdagangan;

2) Kepala Dinas Pertanian dan Perkebunan.

Kelompok Program-Program Lainnya/Program Pro-Rakyat:
a. Ketua
b. Ketua
c. Anggota

Asiten Administrasi Umum Kepala Dinas Tenaga Kerja

1) Kepala Bagian Hukum;

2) Kepala Bagian Perekonomian.

B. SUSUNAN SEKRETARIAT dan KELOMPOK KERJA TKPK KABUPATEN KEDIRI: SEKRETARIAT TKPK:

1. Kepala

2. Wakil Kepala

3. Anggota

\section{KELOMPOK KERJA TKPK}

1) Kelompok Kerja Pendataan dan Sistem Informasi:
a. Ketua
b. Wakil Ketua

d. Anggota
Sekretaris Bappeda Sekretaris Dinas Pemberdayaan Masyarakat dan Pemerintahan Desa

1) Kasubag Program pada Bappeda;

2) Kasubag Penyusunan Program pada Dinas Pemberdayaan Masyarakat dan Pemerintahan Desa

Kepala Bidang Penanganan Fakir Miskin Dinas Sosial

Kepala Seksi Statistik Sosial pada BPS

1) Kepala Dinas Kependudukan dan Pencatatan Sipil;

2) Kepala Dinas Komunikasi dan Informatika;

3) Kepala Bidang I Pembangunan Manusia dan Masyarakat Bappeda;

4) Kepala Sub Bidang I Pembangunan Manusia dan Masyarakat pada Bappeda;

5) Kepala Sub Bidang II Pembangunan Manusia dan Masyarakat pada Bappeda;

6) Kepala Sub Bidang III 
2) Kelompok Kerja Pengembangan Kemitraan:
a. Ketua
b. Wakil Ketua

d. Anggota

3) Kelompok Kerja Pengaduan Masyarakat:
a. Ketua
b. Wakil Ketua
d. Anggota

Pembangunan Manusia dan Masyarakat pada Bappeda;

7) 4 (empat) staf Bidang I Pembangunan Manusia dan Masyarakat pada Bappeda.

Kepala Bidang II Ekonomi dan Sumber Daya Alam pada Bappeda Kepala Bagian Perekonomian

1) Kepala Bidang Pemberdayaan Usaha Ekonomi Masyarakat dan Bantuan Pembangunan Desa pada Dinas Pemberdayaan Masyarakat dan Pemerintahan Desa;

2) Kepala Bidang Pembiayaan dan Pemasaran pada Dinas Koperasi dan Usaha Mikro.

Kepala Bidang Penguatan Kelembagaan dan Pengembangan Partisipasi Masyarakat pada Dinas Pemberdayaan Masyarakat dan Pemerintahan Desa

Sekretaris lnspektorat 6 (enam) Staf Unit Pengelolaan

Pengaduan Masyarakat.

\section{Koordinasi Penanggulangan Kemiskinan.}

Karena tugas TKPKD sebagian besar terkait dengan koordinasi penanggu-langan kemiskinan, maka kegiatan-kegiatan yang dilaksanakan oleh TKPKD Kabupaten Kediri umumnya berupa rapat-rapat koordinasi, yaitu:

Rapat koordinasi tingkat daerah (Kabupaten Kediri dan Provinsi Jawa Timur); dan Rapat koordinasi dengan kelembagaan di tingkat pusat.

Kegiatan Rapat Koordinasi TKPK Kabupaten Kediri melibatkan seluruh unsur yang terlibat dalam struktur TKPKD Kabupaten Kediri. Selaku penang-gungjawab, Bupati Kediri berperan penting dalam menggerakkan seluruh elemen untuk mensukseskan program dan kegiatan penanggulangan kemis-kinan di Kabupaten Kediri.

Di samping rapat-rapat koordinasi, TKPK Kabupaten Kediri juga melakukan kegiatan fasilitasi beberapa kegiatan penanggulangan kemiskinan yang dilak-sanakan oleh pihak swasta maupun secara mandiri (swadaya masyarakat).

\section{Pengendalian Penanggulangan Kemiskinan.}

\section{Monitoring dan Evaluasi Penanggulangan Kemiskinan.}

Pelaksanaan monitoring dan evaluasi terhadap program dan kegiatan penang-gulangan kemiskinan di Kabupaten Kediri dilaksanakan dengan mengamati pencapaian indikator program dan kegiatan dalam tahapan sebagai berikut:

1. masukan (input);

2. kegiatan (process);

3. keluaran (output);

4. sasaran (outcome);

5. tujuan (goals). 
Monitoring dan evaluasi penanggulangan kemiskinan dilakukan terhadap:

1. monitoring terhadap pelaksanaan program penanggulangan kemiskinan yang ada di setiap bidang Perangkat Daerah;

2. monitoring terhadap program penanggulangan kemiskinan bersasaran;

3. evaluasi terhadap output program-program penanggulangan kemiskinan yang ada di setiap bidang Perangkat Daerah;

4. evaluasi terhadap capaian indikator-indikator (outcome) kemiskinan.

Metode yang digunakan dalam melakukan monitoring dan evaluasi antara lain:

1. survey: mengumpulkan informasi yang relevan dari responden yang diper- oleh dari sampel yang representative

2. metode partisipatif: mendapatkan informasi dengan cara pelibatan secara intensif dan observasi langsung dalam kurun waktu tertentu

3. analisis anggaran: menganalisis item-item pengeluaran program dan mem- bandingkan dengan rencana awal

4. kunjungan lapangan (spot check/rapid appraisal): Perolehan informasi secara cepat dari penerima program dan pemangku kepentingan lainnya. Perolehan informasi secara cepat dari penerima program dan pemangku kepentingan lainnya.

Monitoring dan evaluasi dilakukan oleh Tim Koordinator Program dalam TKPK bersama dengan Perangkat Daerah terkait yang menjadi Satuan Kerja (Satker) pelaksana dari setiap Program dan kegiatan dimaksud.

Secara rutin setiap tahun TKPK Kabupaten Kediri melakukan kegiatan monitoring dan evaluasi program-program penanggulangan kemiskinan di wilayah kerja Kabupaten Kediri.

\section{Penanganan Pengaduan Masyarakat.}

Secara luas, pengertian pengaduan masyarakat pada program dan kegiatan penanggulangan kemiskinan di Kabupaten Kediri adalah langkah tindakan masyarakat yang ditujukan pada Pemerintah Kabupaten Kediri, menyangkut:

$\square$ Upaya masyarakat untuk memperoleh informasi/kejelasan mengenai suatu program/kegiatan atau pelayanan yang terkait dengan masyarakat miskin;

- Upaya masyarakat untuk menyampaikan keluhan terkait dengan pela-yanan yang diterima oleh masyarakat miskin;

- Upaya masyarakat untuk menyampaikan komplain terkait dengan keru-gian yang di alami oleh masyarakat miskin akibat pelaksanaan pembangunan.

\section{KESIMPULAN DAN SARAN}

\section{Kesimpulan.}

Kondisi Kemiskinan Multidimensi:

- persentase penduduk miskin di Kabupaten Kediri dalam lima tahun ter-akhir menunjukkan trend menurun meskipun tidak terlalu progresif dengan rata-rata penurunan sebesar 0,28 persen per-tahun;

- tahun 2017, persentase penduduk miskin Kabupaten Kediri mengalami penurunan sebesar 0,47\% ( \pm 191 ribu jiwa) terhadap kondisi tahun 2016;

- tahun 2017, capaian angka-angka kemiskinan berdasarkan dimensi eko-nomi masih menunjukkan posisi lebih tinggi terhadap capaian Provinsi Jawa Timur maupun capaian secara Nasional; 
- $\quad$ perkembangan TPT dalam 5 tahun terakhir menunjukkan trend menurun, dengan posisi capaian tahun 2017 di bawah capaian Provinsi Jawa Timur dan Nasional;

- indikator-indikator yang perlu perhatian (fokus) untuk mendapatkan intervensi berupa kebijakan dan program untuk memperbaiki capaian saat ini adalah sebagaimana tabel berikut:

\begin{tabular}{|c|c|c|c|}
\hline \multirow[b]{2}{*}{ Bidang } & \multirow{2}{*}{$\begin{array}{l}\text { Indikator yang perlu } \\
\text { mendapat Intervensi }\end{array}$} & \multicolumn{2}{|c|}{ Keterangan } \\
\hline & & $\begin{array}{c}\text { Posisi Relatif terhadap } \\
\text { capaian Provinsi \& Nasional }\end{array}$ & Perkembangan Antar-Waktu \\
\hline$(1)$ & $(2)$ & (3) & $(4)$ \\
\hline \multirow[t]{3}{*}{ Pendidikan } & APK dan APM SD/MI & $\begin{array}{l}\text { lebih tinggi dari capai-an } \\
\text { Provinsi \& Nasional }\end{array}$ & $\begin{array}{l}\text { Fluktuatif, trend cenderung } \\
\text { menu-run, capaian } 2017 \text { turun } \\
\text { thdp } 2016 \text {. }\end{array}$ \\
\hline & $\begin{array}{l}\text { APK dan APM SMA/ } \\
\text { SMK/MA }\end{array}$ & $\begin{array}{l}\text { lebih rendah dari capai-an } \\
\text { Provinsi \& Nasional }\end{array}$ & Konsisten mening-kat \\
\hline & $\begin{array}{l}\text { APtS usia 7-12 tahun dan } \\
\text { usia 15-18 tahun }\end{array}$ & $\begin{array}{l}\text { lebih tinggi dari capai-an } \\
\text { Provinsi \& Nasional }\end{array}$ & $\begin{array}{l}\text { Fluktuatif, trend cenderung } \\
\text { menu-run, capaian } 2017 \text { turun } \\
\text { thdp 2016. }\end{array}$ \\
\hline \multirow[t]{2}{*}{ Kesehatan } & $\begin{array}{l}\text { Rasio Bidan per } 100 \text { ribu } \\
\text { penduduk }\end{array}$ & $\begin{array}{l}\text { lebih rendah dari capai-an } \\
\text { Provinsi \& Nasional }\end{array}$ & $\begin{array}{l}\text { Fluktuatif, trend cenderung } \\
\text { menu-run, capaian } 2017 \text { naik } \\
\text { thdp 2016. }\end{array}$ \\
\hline & $\begin{array}{l}\text { Proporsi } \begin{array}{r}\text { persalinan } \\
\text { ditolong oleh } \\
\text { kesehatan terlatih }\end{array} \\
\end{array}$ & $\begin{array}{l}\text { lebih rendah dari capai-an } \\
\text { Provinsi, lebih baik dari } \\
\text { capaian Nasional }\end{array}$ & $\begin{array}{l}\text { Fluktuatif, trend cenderung } \\
\text { me-ningkat, capaian } 2017 \text { naik } \\
\text { thdp 2016. }\end{array}$ \\
\hline \multirow[t]{3}{*}{ Prasarana Dasar } & Rumah tidak layak huni & $\begin{array}{l}\text { lebih tinggi dari capai-an } \\
\text { Provinsi\& Nasional }\end{array}$ & $\begin{array}{l}\text { hanya tersedia data } 2 \text { th terakhir, } \\
\text { capaian } 2017 \text { lebih rendah dari } \\
2016\end{array}$ \\
\hline & $\begin{array}{l}\text { Rumah tangga dg akses } \\
\text { listrik }\end{array}$ & \multirow{2}{*}{$\begin{array}{l}\text { lebih rendah dari capai-an } \\
\text { - Provinsi, lebih baik dari } \\
\text { capaian Nasional }\end{array}$} & \multirow{2}{*}{$\begin{array}{l}\text { Fluktuatif, trend cenderung } \\
\text { me-ningkat, capaian } 2017 \text { turun } \\
\text { thdp } 2016 .\end{array}$} \\
\hline & $\begin{array}{l}\text { Rumah tangga dg status } \\
\text { kepemilikan milik sendiri }\end{array}$ & & \\
\hline Ketahanan & Rata-rata harga beras & & \\
\hline Pangan & Rata $^{2}$ harga non-beras & & \\
\hline
\end{tabular}

Indikator yang tidak disebutkan di atas, telah menunjukkan kondisi yang baik, baik terhadap posisi relatif maupun perkembangan antar waktunya.

1. Kebijakan Penanggulangan Kemiskinan:

- belum memiliki regulasi (Perda atau Perbup) yang secara spesifik mencantumkan kemiskinan sebagai isu utama pada regulasi tersebut;

- program/kegiatan yang terkait (langsung maupun tidak langsung) dengan penanggulangan kemiskinan, memiliki kualifikasi:

\begin{tabular}{|l|c|}
\hline $\begin{array}{l}\text { perencanaan program/kegiatan diawali dengan analisis fokus masalah pada } \\
\text { masing-masing indilkator dimensi kemiskinan }\end{array}$ & belum \\
\hline $\begin{array}{l}\text { perencanaan program/kegiatan memperhatikan analisis De-terminan } \\
\text { kemiskinan masing-masing dimensi kemiskinan }\end{array}$ & $\checkmark$ \\
\hline $\begin{array}{l}\text { penerima manfaat program/kegiatan berdasarkan basis data kemiskinan } \\
\text { terpadu (BDT) }\end{array}$ & $\checkmark$ \\
\hline $\begin{array}{l}\text { penetapan wilayah sasaran program/kegiatan ditentukan melalui analisis } \\
\text { kuadran untuk mentukan prioritas wilayah }\end{array}$ & $\checkmark$ \\
\hline antar program/kegiatan menunjukkan komplementaritas program/kegiatan & $\checkmark$ \\
\hline
\end{tabular}


- ruang fiskal pendapatan daerah masih di bawah 50 persen, dengan rasio ketergantungan fiskal yang tinggi (di atas 50 persen), dengan demikian Kabupaten Kediri sangat tergantung dengan pihak eksternal dalam membiayai programprogramnya, termasuk program penanggulangan ke-miskinan.

2. Kelembagaan Penanggulangan Kemiskinan:

a. Tim Koordinasi Penanggulangan Kemiskinan (TKPK) Kabupaten Kediri telah terbentuk dengan Surat Keputusan Bupati Kediri tentang Tim Koordinasi Penanggulangan Kemiskinan Kabupaten Kediri Tahun 2017;

b. kinerja TKPK masih perlu ditingkatkan, dalam hal:

- koordinasi dalam rangka sinkronisasi dan harmonisasi program penang-gulangan kemiskinan antar Perangkat Daerah;

- pengendalian melalui monitoring dan evaluasi serta pengelolaan peng-aduan masyarakat;

c. sarana dan prasarana kesekretariatan TKPK masih belum memadai.

\section{Rekomendasi.}

Ditujukan kepada

Pemerintah Kab.

Kediri

\section{Isi Rekomendasi}

1) mempertahankan upaya-upaya (kebijakan dan program) penanggulangan kemiskinan yang telah menunjukkan hasil capaian yang baik pada tahun ini;

2) lebih memperkuat pelaksanaan program penanggulangan kemiskinan melalui kebijakan yang berupa peraturan, baik berupa Peraturan Daerah (Perda) atau Peraturan Bupati (Perbup), dan aturan pelaksanaan-nya yang secara jelas mencantumkan kemiskinan sebagai isu utama, misalnya:

- Perda tentang penanggulangan kemiskinan;

- Tata cara/mekanisme pemanfaatan data BDT (Basis Data Terpadu) tahun 2015 yang telah di update oleh TKPK Kabupaten, bagi Perangkat Daerah dalam menyu-sun program dan kegiatan penanggulangan kemiskinan; dan lain sebagainya dan lain sebagainya.

3) mengembangkan PROGRAM INOVASI DAERAH berbasis pemberdayaan masyarakat, guna mengimbangi program-program penanggulangan kemiskinan yg selama ini telah ada dan hanya bersifat charity, sekaligus untuk mewujud kan strategi peningkatan pendapatan penduduk miskin.

Sekretaris TKPK memperkuat Sekretariat TKPK dengan:

- menyediakan peralatan yang sesuai kualifikasi untuk pengelolaan data kemiskinan;

- melatih personil kesekretariatan agar memiliki kualifikasi dalam mengelola datadata kemiskinan menjadi informasi yang up to date.

Ketua Pokja Data \& In-formasi, TKPK mengembangkan Sistem Informasi Manajemen (SIM) data kemiskinan daerah terpadu dengan memanfaatkan basis data BDT dan data lain-nya. 
Ditujukan kepada

Ketua Pokja

Kemitraan, TKPK
Isi Rekomendasi
- meningkatkan keterlibatan masyarakat, dunia usaha, dan pe-mangku kepentingan lainnya dalam penanggulangan kemis-kinan, seperti pelaku CSR (corporate social respon-sibility), Perguruan Tinggi, LSM, dan Media;

- menyusun directory lembaga mitra program yg telah siap bermitra dalam program penanggulangan kemiskinan.
Ketua Pokja

Pengaduan Masyarakat,

TKPK

Wakil Ketua TKPK
- merumuskan mekanisme penanganan pengaduan masyarakat;

- menyiapkan personil pengelola pengaduan masyarakat;

- mengembangkan sistem pengaduan berbasis web. meningkatkan kuantitas dan kualitas koordinasi, sinkronisasi dan harmonisasi program dan data penanggulangan kemiskinan di internal klaster maupun antar klaster.

\section{DAFTAR PUSTAKA}

Badan Pusat Statistik, 2011, Ensiklopedia Indikator Ekonomi dan Sosial, Jakarta.

Badan Pusat Statistik Provinsi Jawa Timur, 2018, Keadaan Angkatan Kerja di Provinsi Jawa Timur - Agustus 2017, Surabaya.

Badan Pusat Statistik Provinsi Jawa Timur, 2018, Produk Domestik Regional Bruto Provinsi Jawa Timur Menurut Lapangan Usaha Tahun 2013-2017, Surabaya.

Badan Pusat Statistik Provinsi Jawa Timur, 2018, Statistik Kesehatan Provinsi Jawa Timur 2017, Surabaya.

Badan Pusat Statistik Provinsi Jawa Timur, 2018, Statistik Pendidikan Provinsi Jawa Timur 2017, Surabaya.

Badan Pusat Statistik Provinsi Jawa Timur, 2018, Statistik Pengeluaran untuk Konsumsi Rumah tangga Provinsi Jawa Timur 2017, Surabaya.

Dinas Kesehatan Kabupaten Kediri, 2017, Profil Kesehatan Kabupaten Kediri Tahun 2017, Kediri.

Dinas Kesehatan Provinsi Jawa Timur, 2018, Profil Kesehatan Provinsi Jawa Timur Tahun 2017, Surabaya.

Kementerian Kesehatan Republik Indomesia, 2018, Data dan Informasi Profil Kesehatan Indonesia 2017, Jakarta. 
Kementerian Perencanaan Pembangunan Nasional/Badan Perencanaan Pembangunan Nasional, 2010, Buku III - Alat Analisis Tepat Guna untuk Perencanaan dan Penganggaran yang Berpihak pada Masyarakat Miskin, Jakarta.

Tim Nasional Percepatan Penanggulangan Kemiskinan (TNP2K), 2010, Panduan Praktis Analisis Data Untuk Mendukung Koordinasi Penanggulangan Kemiskinan, Jakarta.

Tim Nasional Percepatan Penanggulangan Kemiskinan (TNP2K), 2014, Petunjuk Teknis Penyusunan SPKD - Buku Pegangan Resmi TKPK Daerah, Jakarta.

------, Outline, Penyusunan Laporan Pelaksanaan Penanggulangan Kemiskinan - Tahun 2013, ---

, http://bps.go.id

, http://jatim.bps.go.id

, http://kedirikab.bps.go.id 